\title{
完全独立分割セルを用いた高分子形燃料電池のセル特性解析
}

\author{
行天 久朗
}

パナソニック株式会社先端技術研究所（－619-0237 京都府相楽郡精華町光台 3-4）

\section{Performance Analysis of Polymer Electrolyte Membrane Fuel Cell by Perfectly Insulated Segmented Cells}

\author{
Hisaaki Gyoten \\ Advanced Technology Research Laboratory, Panasonic Corporation (3-4 Hikaridai, Seika-cho, Soraku-gun, Kyoto \\ 619-0237, Japan)
}

Received July 10, 2010 ; Accepted August 23, 2010

\begin{abstract}
To investigate local phenomena of water flooding or drying up in a polymer electrolyte membrane fuel cell, a segmented cell consisting of perfectly insulated 5-cells was fabricated. The gas flow channels were designed to provide the reactant gases for a series of 5-cells in single direction without gas mixing or backflow under the operation. Through the I-V measurements of each cell varying oxygen utilization, dew point, gas pressure, and temperature gradients along gas flow, the local humidity conditions of each cell were analyzed. The local phenomena of water flooding or drying up and their influences on the overall cell performance can be understood well by introducing the $\mathrm{H}_{2} \mathrm{O}$ vapor transportation index.
\end{abstract}

Key Words : PEFC, Segmented Cell, Water Flooding, Vapor Transportation Index

\section{1 緒 言}

燃料電池は反応ガスをガス拡散電極の一端から連続的に供 給し，電気化学反応によって発電する一種の連続反応装置な ので，反応ガス濃度差や温度差がつくことは避けられない。 その結果, セル内の物質濃度や温度の異なる部位で発電性能 に差が生じることになるが，あまり性能差が大きくなると内 部電流によってセル全体としての性能は低下する ${ }^{1,2}$ 。また 反応の集中によって，局所的に高温になったり作動条件が触 媒や電解質の耐久許容值を外れるとその部位で耐久劣化が進 む. その局所劣化は電流密度分布やガス配流性にフィードバ ックされて，セル内の作動条件の分布幅をさらに大きくする ので，耐久劣化を加速することになる．特に高分子電解質燃 料電池では, 飽和水蒸気圧が大きく変化する温度域（60～ $90{ }^{\circ} \mathrm{C}$ ) で動作し, 高分子電解質のプロトン伝導度が反応ガ スの相対湿度に大きく依存するので 3 ， セル内の反応ガスの 加湿状態の分布を把握, 制御することは, 性能と耐久性を確 保する上で最も重要である。

カソード触媒層では, 高分子電解質と $\mathrm{Pt} / \mathrm{C}$, 気孔が接す る三相带へ酸素とプロトンが当量供給されることによって燃 料電池反応が起こる．しかしながら反応による生成水や凝縮 水が触媒層やガス拡散層（GDL）内に滞留すると，三相帯へ の酸素の供給が悪くなって性能が低下（フラッディング）す る。一方, 低加湿下で膜や触媒層中のバインダーのプロトン 伝導度が低下しても性能低下（ドライアップ）が起こる。ま た耐久性に関しては，フラッディングするような高加湿条件 下では，触媒層中の Ptの溶出による劣化 $\left.{ }^{4,5}\right)$ が起こりやすく
なり，逆にドライアップ条件下では，フッ素系電解質膜がフ ッ化物イオンを放出して分解する劣化が起こりやすくなる.

一般的にセル内の反応分布解析には分割セルが用いられる が，GDLなどの電子伝導体が共通になっていると, 分割し た電極で発生した電流がわずかの電位差によって隣接するセ ルのセパレーターや集電体に流れ, 正確な電流密度や発生電 圧の把握が困難になる。また，反応ガスが途中で分割セル間 を逆流したり, 分岐・混合したりすると, 分割セルごとの加 湿状態や，圧損による圧力変化の考察，解析が難しくなる. そこで本研究では, GDLを含めて電子伝導体が相互に絶縁 されていて，かつ全体としてのガス流れに沿って順に5分割 された分割セルを作成し, カソード入口に供給する反応ガス の流量や露点, 圧損を変化させて各分割セルの特性を測定し, セル内部での加湿状態の分布と電池特性について解析を試み た。

\section{2 実 験}

\section{1 固体高分子形完全独立分割セルの構成}

燃料電池セル内の反応解析では, 各種のサンプリングポー 卜を数多く配したり, 透明密や反応試薬を用いてin-situで反 応ガスの状態を調べる方法 ${ }^{6)}$ も有用である. しかしながらそ のような構成にすること自体が電池の作動状態に影響を及ぼ すことがある。 そこで今回の実験では, 各分割セルの発電特 性を, 反応ガスの相対湿度に影響する 4 つの要因, すなわち 1）酸素の消費などによる供給ガス量の変化，2）生成水の気 化や凝縮，3）温度変化，および4）流路圧損による全圧の 
変化の観点 ${ }^{7)}$ から，解析することにより，逆に各分割セルの カソードの加湿状態を推定，把握する方法を採ることにした。 そのため撥水性をコントロールしたガス拡散層を用いること によって，フラッディングとドライアップがクリティカルに 発生し，供給ガスの相対湿度が特性変化に反映されやすい膜 電極接合体（MEA）を用いた。

今回の実験に用いた分割セルを Fig. 1に示す。セパレータ や集電体だけでなくGDLも分割し，各セルが電子伝導的に 完全に独立した 5 分割構成（電極面積 $32 \mathrm{~cm}^{2} /$ 各セル）とし た。隣接する各セルのガス拡散層，カーボンセパレー夕，集 電板の間は，シール性樹脂を用いて接合し，ガスシール性と 電気絶縁性を確保した。

各セルの触媒層は $\mathrm{Pt} / \mathrm{C}$ とナフィオン溶液からなるインク を，Pt担持量が約 $0.3 \mathrm{mg} / \mathrm{cm}^{2}$ となるように，ガス拡散層と して用いたカーボンペーパー（東レ製 TGP-H 厚み 360 $\mu \mathrm{m}$, PTFEデイスパージョンによる撥水処理）上に塗布・ 乾燥して形成した ${ }^{8,9)}$. ガス流路は樹脂含浸カーボンセパレ ー夕（大和田カーボン製）上に形成し，断面積 $1 \mathrm{~mm}^{2}$ のサ ーペンタイン状のガス流路溝をカソード側には 6 本，アノー ド側には 2 本構成した。セル全体として上流（No.1）から下 流（No.5）に分割セルを順に反応ガスが並行流で流れるよう に形成し，ガス拡散層を伏流する反応ガスも上流から下流に 順に連続的に流れるように構成した。アノードガスには純水 素，カソードガスは空気を用い，前段に設けた加湿バブラー, 及び保温パイプの温度と流量の調節によって，全体セルに供 給するガスの温度，加湿露点，及び流量を調整した。

またガス流路とは反対側のセパレータ面には，冷却水流路 を形成し, 冷却水の温度と流量を調整することにより電池温 度を制御する構造とした. 冷却水の流れを反応ガスと同じ方 向にすることによって，冷却水流量を絞った場合には，発電 によって発生した熱によってセル内の温度が上流セルから下 流セルに順に高くできるようにした.

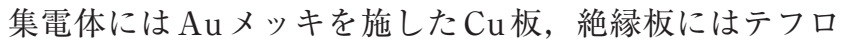
ン板を用いた。エンドプレートにはステンレス板（SUS304） を用いて，5つの分割セルからなる全体セルを $0.6 \mathrm{MPa}$ で締 結した。エンドプレートと絶縁板に設けた開孔を通して，そ

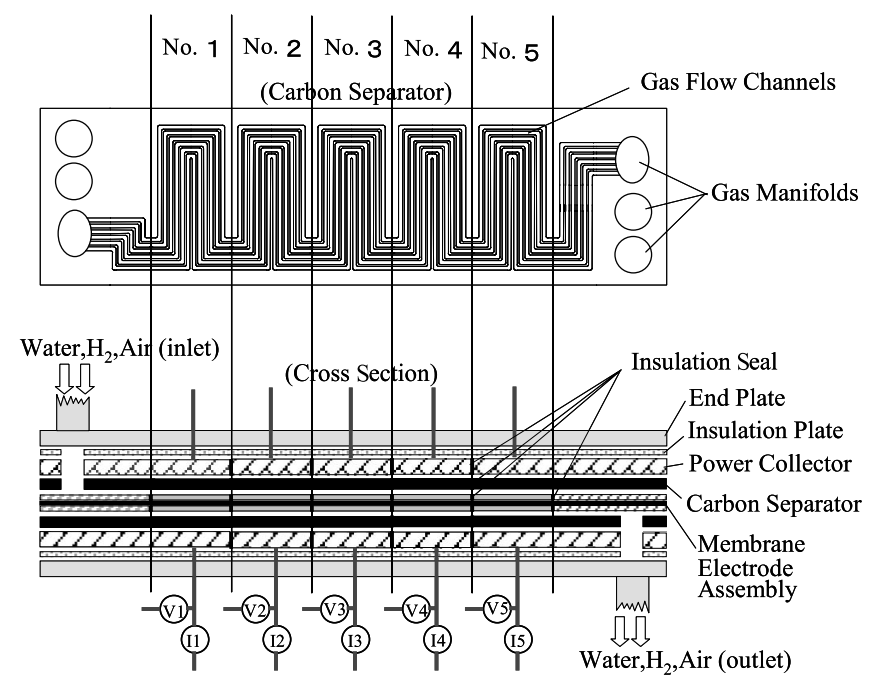

Fig. 1 Design of flow field on carbon separator and cross section of segmented cell describing perfectly insulated 5-cells.
れぞれの分割セルの集電板に直接, 電流/電圧端子を取り付 け，性能評価の際，各セル毎に独立して電流と電圧を設定， 測定できるようにした。それぞれの分割セルのセパレータに は，側面方向から孔を開け，温度計測用の熱電対を MEA 部 の中央まで差し込んで温度計測し，電池温度とした。

\section{3 結 果}

\section{1 高加湿条件運転下でのフラッディング現象}

全ての分割セルの電池温度を $75{ }^{\circ} \mathrm{C}$ と，アノードガスを フル加湿（バブラー温度を電池温度より高い $85{ }^{\circ} \mathrm{C}$ に設定し， パイプ保温温度を電池と同じ $75{ }^{\circ} \mathrm{C}$ に設定), 供給した水素に 対する反応水素の割合である燃料利用率 $\left(U_{\mathrm{f}}\right)$ を $70 \%$, 電 流密度 $0.7 \mathrm{Acm}^{-2}$ で発電した時，カソード入口の空気の露点 $\left(T_{\mathrm{d}}\right)$ と空気利用率 $\left(U_{\mathrm{o}}\right)$ が電池性能に及ぼす影響を Fig. 2 に示した。

$U_{\mathrm{o}}=20 \%$ の時には， $T_{\mathrm{d}}$ が $50 \sim 60{ }^{\circ} \mathrm{C}$ で電池電圧が高く，そ れより低加湿では若干性能が低く, 逆に $T_{\mathrm{d}}$ が $65{ }^{\circ} \mathrm{C}$ の高加湿 ではフラッディングによって性能が低下した。分割セルごと に性能変化を見ていくとカソードガスの下流にあるセルほど 性能が低い傾向が認められるもののセル間に大きな性能の差

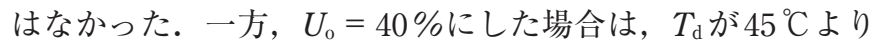
高くなるとNo.3〜No.5の下流セルで急激に電池電圧が低下 した．各分割セルは $0.7 \mathrm{Acm}^{-2}$ の一定の電流密度で作動して いるので，上流の分割セルで酸素が消費されて体積減少した 上に，生成した水蒸気が気化して付与されたカソードガスが 下流の分割セルに供給される。その結果，下流側の分割セル ほど相対湿度が高くなったカソードガスが供給され，フラッ ディングによる大きな性能低下が引き起こされたものと思わ れる。

\section{2 電流密度分布}

通常の高分子形燃料電池セルでは，セパレータやGDLな どの電子伝導体の電導度が高いので，MEA（膜電極接合体）

(a) $U_{\mathrm{o}}=20 \%$

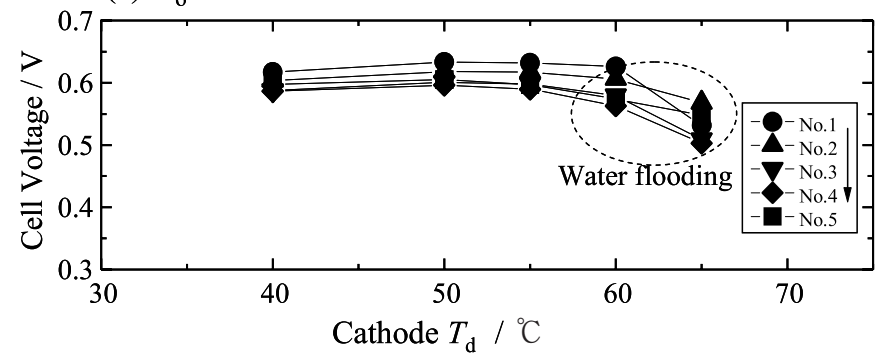

(b) $U_{\mathrm{o}}=40 \%$

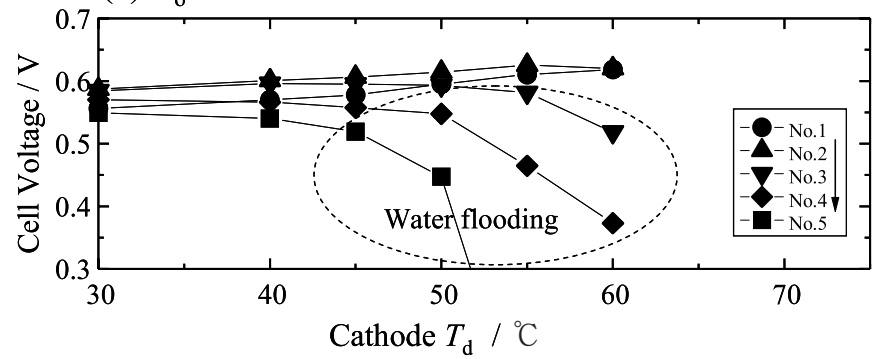

Fig. 2 Dependence of cell voltage for 5-cells on cathode $T_{\mathrm{d}}$, showing the water flooding phenomena under high humidity conditions. 
の各部分は，実質的に一定の電圧下での動作となる．各分割 セル（No.1〜No.5）では，反応ガス（カソードでは酸素ガ ス）の濃度が変化すると共に，相対湿度も変化していくので フラッディングやドライアップによって局所的に性能が異な る。それらの性能差は一定電圧下で運転させた場合は，各分 割七ル間の電流密度差になって表れる。

Fig. 3 には， $U_{0}=40 \%$ とし，全体電圧を一定に保持した時 の各分割セルの電流密度を全体電圧に対してグラフ化したも のである，それぞれの電圧では，最大の電流が出力できるよ うにカソードガスの露点を調整した。アノードガスについて はいずれもフル加湿， $U_{\mathrm{f}}=70 \%$ て定とした。

高負荷（低電圧，高電流密度）になると，上流の分割セル に比べ下流の分割セルに扔ける電流密度低下が著しくなるこ とが分かった。一方，低電流密度 $\left(0.1 \mathrm{Acm}^{-2}\right)$ では，上流 セルの方が下流セルより出力できる電流密度が低くなってい るが，上流セルのドライアップによるものと考えられる.

\section{3 電池内温度分布の影響}

燃料電池セルのフラッディングやドライアップに大きな影 響を及ぼす，もう一つの大きな要因として，電池の作動温度

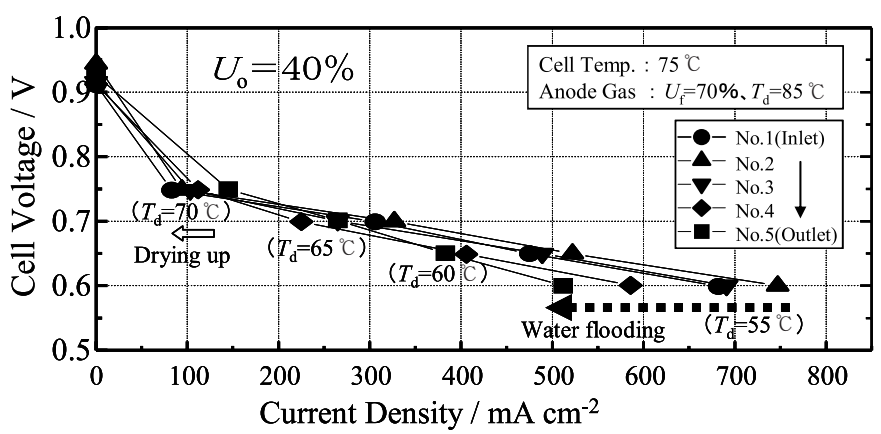

Fig. 3 I-V characteristics of 5-cells, indicating current density distribution, show the water flooding and drying up phenomena in higher and lower current density operations respectively.

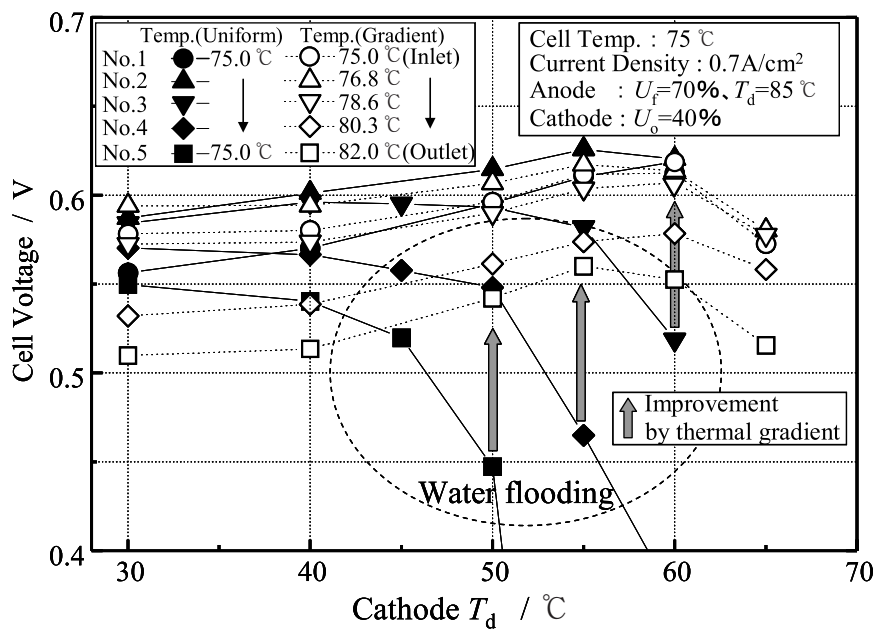

Fig. 4 Cell performance comparison of 5-cells between under uniform temperature operation and gradient temperature operation, indicating that water flooding phenomena in down stream cells under uniform temperature operations were extinguished by temperature gradient operations.
がある．飽和水蒸気圧は温度とともに指数関数的に大きくな るので，上流七ルの生成水によって下流部の水蒸気圧が大き くなっても，温度が高くなれば相対湿度は大きくならず，し たがってフラッディングによる性能低下は顕著にはならない ことが考えられる. Fig. 2の実験では, カソードガスの利用 率を $40 \%$ とすると下流側の分割セルで顕著なフラッディン グが観察されたが，それらのセルがフラッディングに陥らな いように冷却水の流量を徐々に絞って，下流側の分割七ルの 温度を高くして行った. Fig. 49白抜きマークで表したグラ

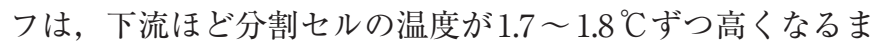
で泠却水流量を絞り込んだ時の， $T_{\mathrm{d}}$ と電池電圧の関係を示し たものである。

セルの上流から下流にかけて温度を高くすることょり，供 給ガス露点が高くなっても下流側分割セルのフラッディング が抑制されることが分かった。しかしながら，低加湿下では 下流の分割セルでは，作動温度の高温化によってドライアッ プが惹起され，電圧が低下することが分かった。

\section{4 カソードガス圧損の影響}

ガス流路には圧損があるので下流では上流に比べて全圧が

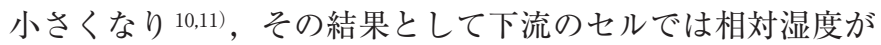
下がり，ドライアップしやすくなる。しかしながら，通常の 燃料電池では, カソードガスの上流部で発生する水蒸気が下 流部の相対湿度を上げるので，ドライアップ効果は現れにく い.そこで次にカソードガス圧損のドライアップ効果に及ぼ す影響を明らかにするため, 注目している分割セルのみ発電 させ，他の分割セルは発電を停止させてドライアップ現象を 検証する実験を行なった。

カソードガスの空気利用率を $20 \%$ としてガス入り口側の 圧力を $1430 \mathrm{hPa}$ ，ガス出口側は開放 (大気圧) とした条件 で，まず全ての分割セルを $0.7 \mathrm{Acm}^{-2}$ で発電し，次にカソー ドガスの全体流量は変えずに，それぞれの分割セルのみを順 に0.7 $\mathrm{Acm}^{-2}$ で単独で発電させた。この実験でもアノードガ スについてはフル加湿, $U_{\mathrm{f}}=70 \%$ で一定とした。

Fig. 5 に示すように全分割セル作動時では, 下流に位置す る分割セルで若干性能が低くなる傾向はあるものの，低加湿 領域でも比較的高い特性が得られた。一方, 分割セルの単独

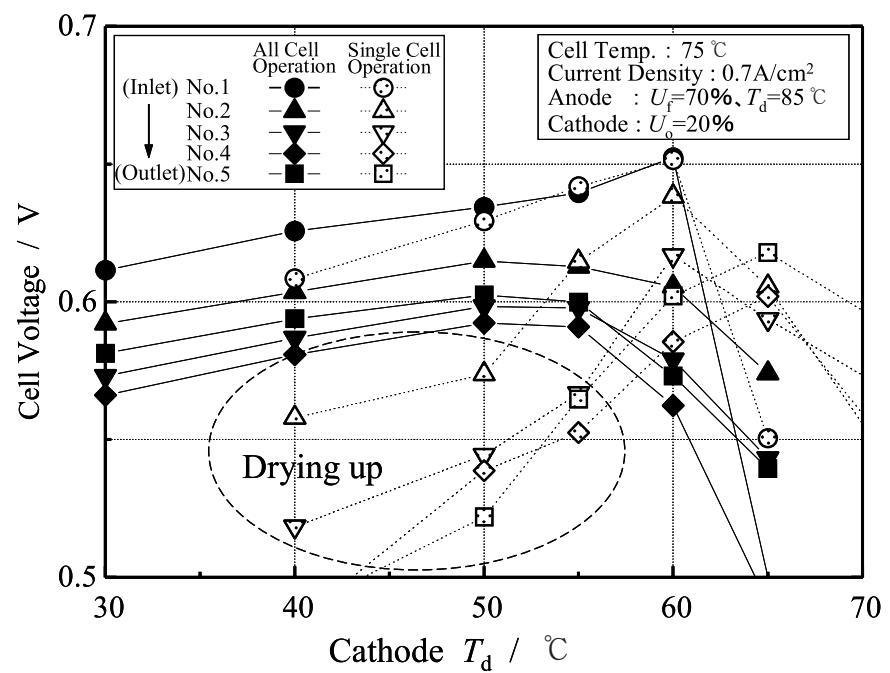

Fig. 5 Cell performance comparison of 5-cells between under all cell and single cell operations. 
作動の場合には，酸素の消費によるガス流量の減少が少なく なる上に，より上流に位置するセルからの生成水付与も無く なる。したがって低加湿領域では圧損によるドライアップが 全セル作動の場合に比べて格段に顕著になり，下流セルほど その性能低下が大きくなることが分かった。

\section{4 考 察}

高分子形燃料電池のドライアップやフラッディング現象は, 直接的には触媒層の含水状態に対応しているが，運転条件と しては供給ガスの相対湿度に依存すると考えられる。本研究 に扔いても，得られた実験結果を，まず相対湿度を中心に整 理した. すなわち, Fig. 2〜 Fig. 5のデー夕に対応した様々 な運転条件下での各分割セル（No.1～No.5）に供給される カソードガスの相対湿度 $(R H), \mathrm{O}_{2}$ 濃度，ガス流速を，上流 セルでの電流密度と水蒸気生成, 全圧の変化（ガス圧損）, 各分割セルの温度を考慮して見積もった。用いた計算式は次 の通り。

$$
\begin{aligned}
& P_{\mathrm{H} 2 \mathrm{O}}^{\mathrm{S}}(T)=6.11 \times 10^{\frac{7.5 T}{T+237.3}} \\
& W(\mathrm{n})=\frac{60 S \sum_{1}^{5} I(\mathrm{i})}{4 \mathrm{~F} U_{0} P_{\mathrm{O}_{2}}} \times \frac{P_{\mathrm{H}_{2} \mathrm{O}}^{\mathrm{S}}\left(T_{\mathrm{d}}\right)}{P(1)-P_{\mathrm{H}_{2} \mathrm{O}}^{\mathrm{S}}\left(T_{\mathrm{d}}\right)}+\frac{120 S\left(\sum_{1}^{\mathrm{n}} I(\mathrm{i})-I(\mathrm{n})\right)}{4 \mathrm{~F}} \\
& V(\mathrm{n})=\frac{60 S_{1}^{5} I(\mathrm{i})}{4 \mathrm{~F} U_{\mathrm{O}} P_{\mathrm{O}_{2}}} \times \frac{P(1)}{P(1)-P_{\mathrm{H}_{2} \mathrm{O}}^{\mathrm{s}}\left(T_{\mathrm{d}}\right)}+\frac{60 S\left(\sum_{1}^{\mathrm{n}} I(\mathrm{i})-I(\mathrm{n})\right)}{4 \mathrm{~F}} \\
& O(\mathrm{n})=\frac{60 S \sum_{1}^{5} I(\mathrm{i})}{4 \mathrm{~F} U_{\mathrm{o}}}-\frac{60 S\left(\sum_{1}^{\mathrm{n}} I(\mathrm{i})-I(\mathrm{n})\right)}{4 \mathrm{~F}} \\
& P_{\mathrm{H} 2 \mathrm{O}}(\mathrm{n})=\frac{W(\mathrm{n}) \times P(\mathrm{n})}{V(\mathrm{n})} \\
& R H(\mathrm{n})=\frac{100 P_{\mathrm{H}_{2} \mathrm{O}}(\mathrm{n})}{P_{\mathrm{H}_{2} \mathrm{O}}(T(\mathrm{n}))} \\
& P_{\mathrm{O}_{2}}(\mathrm{n})=\frac{O(\mathrm{n}) \times P(\mathrm{n})}{V(\mathrm{n})} \\
& v(\mathrm{n})=V(\mathrm{n}) \times \frac{22400}{360 P(\mathrm{n})} \quad \times \frac{273.15+T}{273.15}
\end{aligned}
$$

\begin{tabular}{|c|c|c|}
\hline $\mathrm{F}$ & :ファラデー定数 & {$\left[\mathrm{C} \mathrm{mol}^{-1}\right]$} \\
\hline$T_{\mathrm{d}}$ & :カルードガス加湿器の温度 & {$\left[{ }^{\circ} \mathrm{C}\right]$} \\
\hline$T(\mathrm{n})$ & :第nセルの温度 & {$\left[{ }^{\circ} \mathrm{C}\right]$} \\
\hline$S$ & :分割セルの電極面積 & {$\left[\mathrm{cm}^{2}\right]$} \\
\hline$I(\mathrm{n})$ & :第nセルの電流密度 & {$\left[\mathrm{A} \mathrm{cm}^{-2}\right]$} \\
\hline$U_{\mathrm{o}}$ & :カルードガス利用率 & [\%] \\
\hline$P_{\mathrm{O} 2}$ & :標準状態空気の酸素分圧 & {$[\mathrm{hPa}]$} \\
\hline$P(\mathrm{n})$ & :第nセル入口のガス全圧 & {$[\mathrm{hPa}]$} \\
\hline$P_{\mathrm{H} 2 \mathrm{O}}^{\mathrm{s}}(T)$ & $: T{ }^{\circ} \mathrm{C}$ での飽和水蒸気圧 & {$[\mathrm{hPa}]$} \\
\hline$W(\mathrm{n})$ & :第nセル入口の水蒸気流量 & {$\left[\mathrm{mol} \mathrm{min}^{-1}\right]$} \\
\hline$V(\mathrm{n})$ & :第nセル入口のガス全流量 & {$[\mathrm{mol} \mathrm{min}-1]$} \\
\hline$O(\mathrm{n})$ & :第nセル入口のO ${ }_{2}$ 流量 & {$\left[\mathrm{mol} \mathrm{min} \mathrm{mi}^{-1}\right]$} \\
\hline$P_{\mathrm{H}_{2} \mathrm{O}}(\mathrm{n})$ & :第nセル入口の水蒸気圧 & {$[\mathrm{hPa}]$} \\
\hline$R H(\mathrm{n})$ & :第nセル入口の相対湿度 & [\%] \\
\hline$P_{\mathrm{O}_{2}}(\mathrm{n})$ & :第nセル入口の $\mathrm{O}_{2}$ 分圧 & {$[\mathrm{hPa}]$} \\
\hline$v(\mathrm{n})$ & :第nセル入口のガス流速 & {$\left[\mathrm{m} \mathrm{s}^{-1}\right]$} \\
\hline
\end{tabular}

但し
実際の MEA 中で触媒層の加湿状態は, 発電によって触媒 層にもたらされる水の生成速度と, 触媒層からの排出速度と のバランスによって定まると考えられる。生成水の排出は GDL どの不均一な多孔体中を水蒸気や液体水で輸送され, 一般的には履歴に依存する極めて複雑な現象なので，普遍的 なモデルにして考察するのは難しい. しかしながら，本研究 のように，GDLの撥水状態を制御したMEAの場合は，作動 条件に応じてドライアップとフラッディングが再現性良く発 現することから，GDL中に生成水の仮想的な蒸発面を想定 し, 蒸発面の位置によって触媒層へ酸素の供給が妨げられれ ばフラッディングが起こり, 逆にプロトンの供給が妨げられ ればドライアップ現象が生起すると仮定して, Fig. 6で模式 的に表したような水輸送モデルを立て, 実験結果との整合性 を調べた。 カソードでは電気化学反応により生じる水 $\left(W_{\mathrm{r}}\right)$ に加えて，プロトンに同伴してアノードから運ばれてくるド ラッグ水 $\left(W_{\mathrm{p}}\right)$ や，電解質膜の含水率勾配による拡散水 $\left(W_{\mathrm{d}}\right)$ が生成するが ${ }^{12)}$ ，この水輸送モデルではアノードガス をフル加湿 $(R H=100 \%)$ にし，カソードガスを比較的高 加湿にすることによって拡散水の影響を無視し，プロトン 1

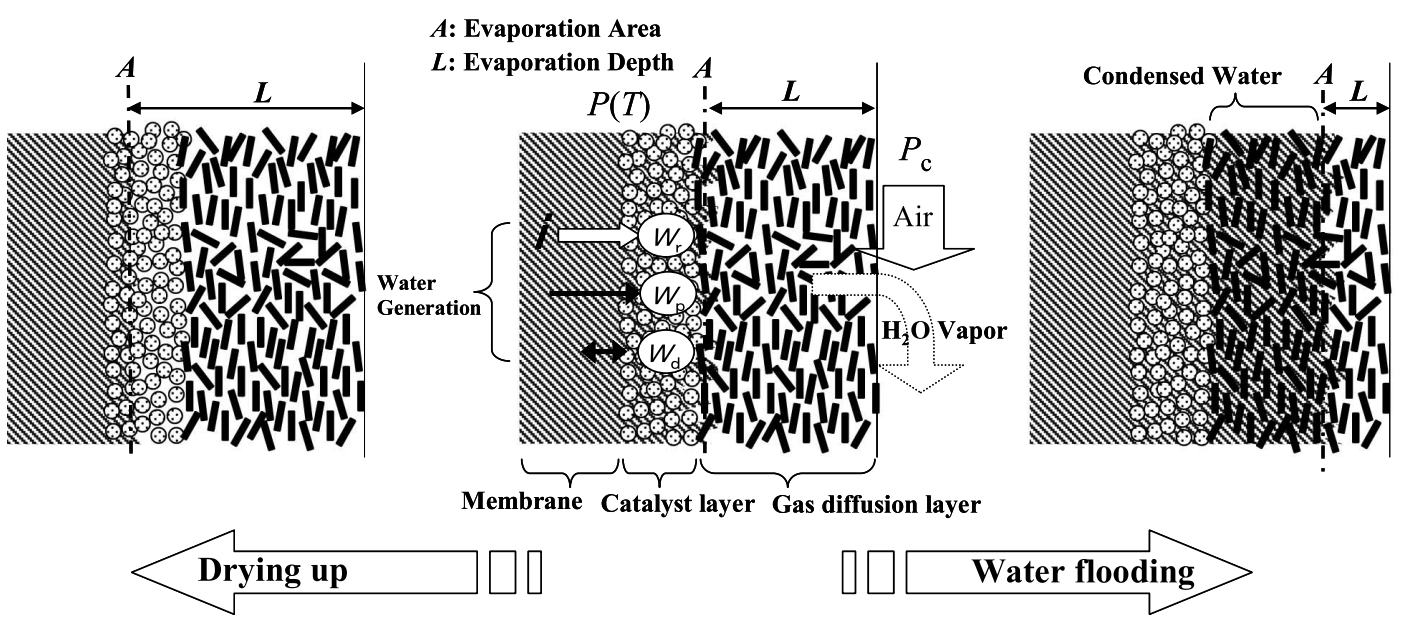

Fig. $6 \mathrm{H}_{2} \mathrm{O}$ vapor transportation model for water flooding and drying up phenomena in a membrane electrode assembly. 
個がドラッグする水分子数も実験条件下では大きく変化しな いとすると，カソードで生成する水 $\left(W_{\mathrm{r}}+W_{\mathrm{p}}+W_{\mathrm{d}}[\mathrm{mol}\right.$ $\left.\left.\mathrm{min}^{-1} \mathrm{~cm}^{-2}\right]\right)$ は，概ね電流密度（I（n） $\left[\mathrm{Acm}^{-2}\right] ） に$ に比例す るとした。

各分割セルでは，反応により生成した水が，蒸発面 Aにお ける飽和水蒸気圧 $\left(P \mathrm{~S}_{\mathrm{H}_{2} \mathrm{O}}(T)\right)$ と, 上流の七ルから供給さ れるカソードガスの水蒸気圧 $\left(P_{\mathrm{H}_{2} \mathrm{O}}(\mathrm{n})\right)$ との差に対応する 濃度拡散によってオフガス中に運び去られると考えると，

$$
W_{\mathrm{r}}+W_{\mathrm{p}}+W_{\mathrm{d}}=W i(\mathrm{n})=\frac{A K\left(P_{\mathrm{H}_{2} \mathbf{0}}^{\mathrm{S}}(T)-P_{\mathrm{H}_{2} \mathbf{0}}(\mathrm{n})\right)}{L}
$$

但し, $K$ : 比例係数 $\left[\mathrm{mol} \mathrm{min} \mathrm{mi}^{-1} \mathrm{~cm}^{-3} \mathrm{hPa}^{-1}\right.$, $A$ : 液体水 の蒸発面の面積 $\left[\mathrm{cm}^{2}\right], L$ : 液体水の蒸発面の深さ $[\mathrm{cm}]$, $W$ : カソードでの生成水量 $\left[\mathrm{mol} \mathrm{min}^{-1} \mathrm{~cm}^{-2}\right]$, と言うモデル 式が得られる。

実際のカソードでは，必ずしもある深さに蒸発面を形成し て液体水が存在するわけではなく，七パレー夕温度と触媒層 温度とのギャップや局所的圧力差によるガス輸送があったり してMEA 中の水蒸気の輸送現象は複雑ではあるが，ここで はあくまで一定の蒸発面（面積 $A$ ）が，GDLの表面からの深 さ $L$ に存在し, カソードで生成した水が拡散方程式に従って 水蒸気としてカソードオフガスに排出されるモデルによって 実際の MEAの特性がどこまで説明できるかを検討した.

$L$ が小さくなると, 生成水の気化は促進されるが反応部 (触媒層) への酸素供給の抵抗が大きくなる結果，性能が低 下寸るフラッディング現象となって表れ，逆にLがガス拡散 層（GDL）の厚みを超えて大きくなるような場合は触媒層の 電解質の含水率が低下して性能が低下するドライアップ現象 が発現すると考えるモデルである。そこで $L に$ に注目してモデ ル式を書き換えると

$$
\begin{aligned}
& L=\frac{A K}{W} \times I_{\mathrm{w}} \\
& I_{\mathrm{w}}=\frac{\left(P_{\mathrm{H}_{0} \mathbf{0}}^{\mathrm{S}}(T)-P_{\mathbf{H}_{\mathbf{2}} \mathbf{0}}(\mathrm{n})\right)}{i(\mathrm{n})}
\end{aligned}
$$

ここで, 今考えている中間の加湿条件では, 蒸発面の位置 は変化するが面積 $A$ はほぼ一定と考え，プロトンのドラッグ 水 $\left(W_{\mathrm{p}}\right)$ も電流密度などによる影響は小さいと仮定すると, 燃料電池内の局所（或いは各分割セル）がフラッディング状 態にあるか，ドライアップ状態にあるかは，水蒸気輸送指標 とも呼ぶべき $I_{\mathrm{w}}$ によって支配的に表すことができると考えら れる.

供給ガスの水蒸気圧や電流密度の高い，すなわち $I_{\mathrm{w}}$ が小さ い作動条件では，発電によって触媒層中で生成する液体水に 対して, 運び去られる水蒸気の方が小さいので，MEA 中に は液体水が滞留してフラッディング状態となり, 逆に水蒸気 圧や電流密度が低くて， I $I_{\mathrm{w}}$ が大きい場合はドライアップ状態 になることが推定できる。

まず，Fig. 2 に示した実験の場合に，各分割セルに供給さ れるカソードガスの加湿条件と発電性能との関係を比較する ため, 相対湿度 $(R H)$ と $I_{\mathrm{w}}$ を計算し, Fig. 7 と Fig. 8 にそれ ぞれ表し，実験より判明したフラッディング領域を重ねて示 した。
Fig. 7 における $R H>50 \%$ の領域，及びFig. 8における $I_{\mathrm{w}}$ $<250$ の領域でフラッデングによると思われる性能低下が表 れていることが分かる。しかしながら，このような電流密度 や作動温度が一定の実験ではMEA の加湿状態を $R H$ と $I_{\mathrm{w}}$ の いずれを指標としても，実際の実駼結果との対応に差がなか った。むしろ同程度の $R H$ や $I_{\mathrm{w}}$ であっても $U_{\mathrm{o}}=20 \%$ に比べ て， $U_{0}=40 \%$ の方がフラッディングによる性能低下が著し く大きく, 式 (7) や式 (8) から導かれる酸素分圧 $\left(P_{\mathrm{O}_{2}}(\mathrm{n})\right)$ やガス流速 $(v(\mathrm{n}))$ の影響も大きいことが分かった. 次に, Fig. 3 で示した電流密度の分布に関しても， $R H$ と $I_{\mathrm{w}}$ を計算 し， $U_{\mathrm{o}}=40 \%$ ものを Fig. 9 (a)，（b）で比較した.

Fig. 3の実際の実験結果と比べると, Fig. 9 （b）における $I_{\mathrm{w}}<250$ ～ 300 の領域と，実際にフラッディングが発生して いる領域が対応し， $I_{\mathrm{w}}$ が最も大きい領域とドライアップと見 られる現象が発生している領域と対応していたが，Fig. 9 (a) で表した $R H$ の分布図では，そのような対応関係が明確では なかった。すなわち電圧の高い低電密領域では，上流のセル ほどドライアップして, GDLから生成水の蒸発面までの距 離 $L$ が大きくなって, 性能が相対的に低くなり, 電圧の低い 高電流密度の領域では，下流のセルで $L$ 小さくなってフラ ッディングに陥り, 性能低下を来たしていることが分かった. このように電流密度を変化させた時, MEAの過湿状態の指 標として $R H$ を用いるより $I_{\mathrm{w}}$ を適用した方が実験結果と良く 一致するのは， $I_{\mathrm{w}}$ の定義式（11）にあるように，電流密度を 考虑することにより生成水の生成速度を直接, 取り达んでい るからと考えられる。

ただ，出力電圧が高い低電流密度の場合にはNo. 5 セルの
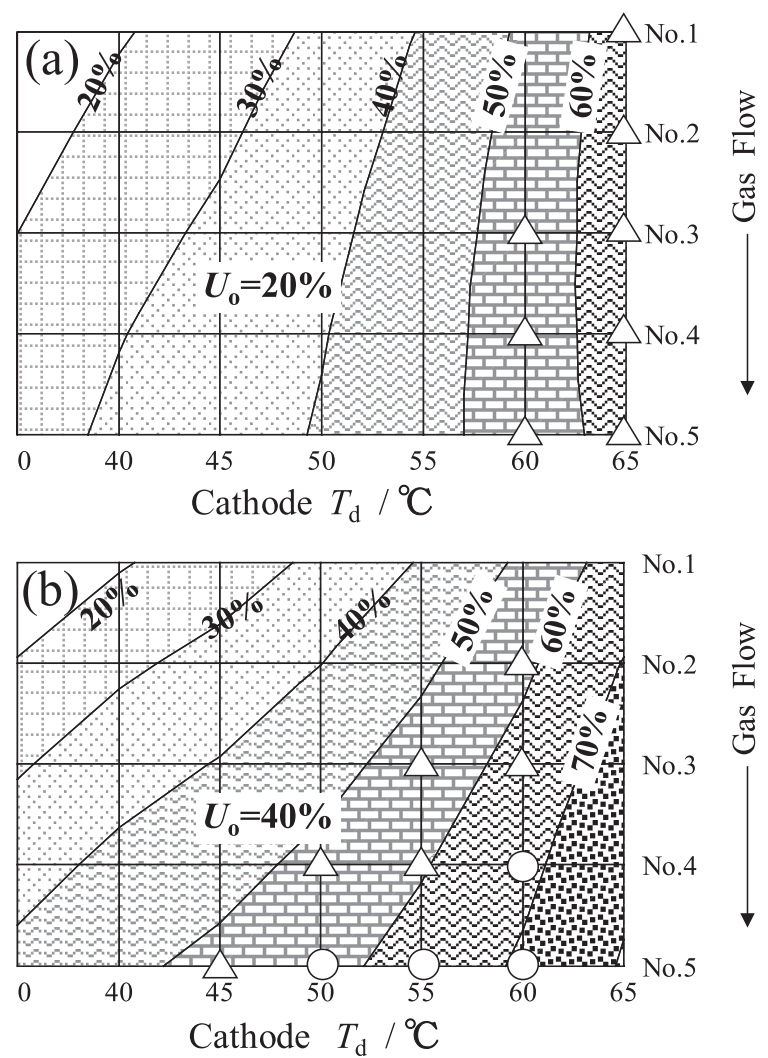

Water Flooding $(\bigcirc$ :strong, $\triangle$ :weak $)$

Fig. 7 Distributions of relative humidity of each segmented cell for (a) $U_{0}=20 \%$, and (b) $U_{0}=40 \%$. 

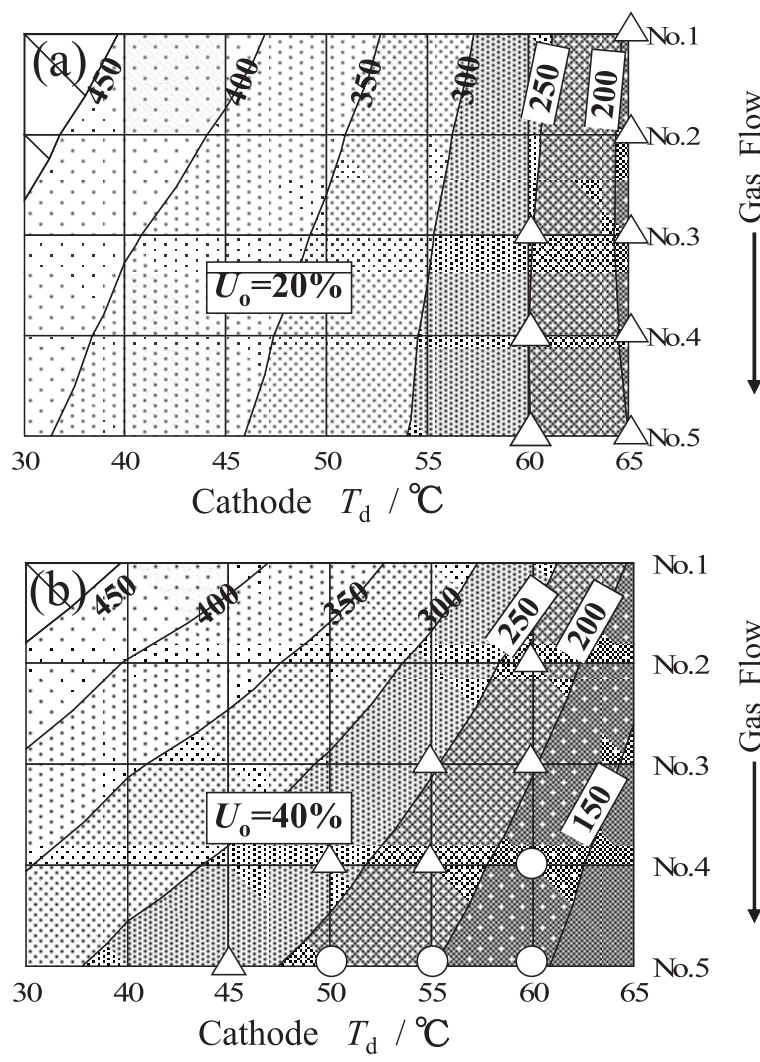

Water Flooding $(\bigcirc$ :strong, $\triangle$ :weak $)$

Fig. 8 Distributions of $\mathrm{H}_{2} \mathrm{O}$ vapor transportation index of each segmented cell for (a) $U_{0}=20 \%$, and (b) $U_{0}=40 \%$.

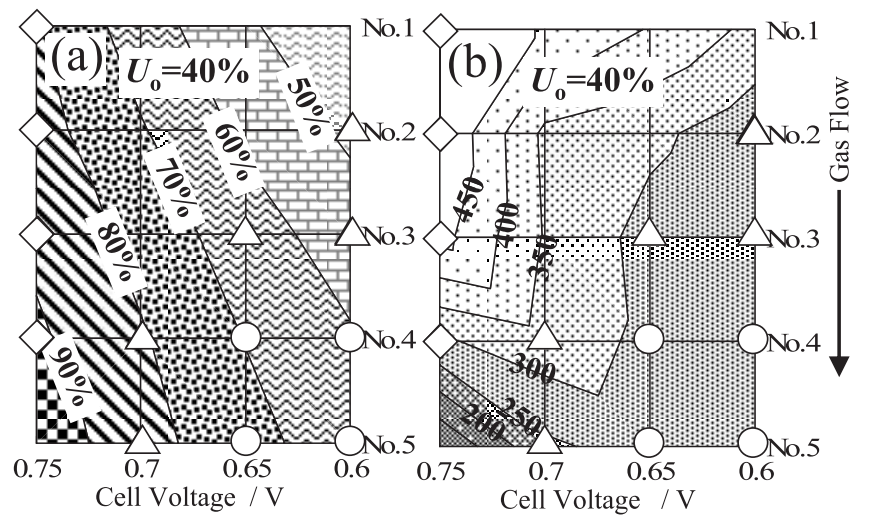

Water Flooding $(\bigcirc$ :strong, $\triangle$ :weak $)$, Drying up $(\diamond)$

Fig. 9 Distributions of (a) relative humidity, and (b) $\mathrm{H}_{2} \mathrm{O}$ vapor transportation index of each segmented cell for varying cell voltages.

ように， $I_{\mathrm{w}}<250$ であってもフラッディング現象を呈しない セルがあるが，このことは MEAがかなり過加湿になった場 合でも，GDLを通じて触媒層中に一定の酸素ガスは供給さ れているか, Fig. 6のようなシンプルな水輸送モデル以外の 水輸送が支配的になっていることを示唆している。

次に冷却水を絞りこむことによって分割セルに温度勾配を つけたFig. 4の実験の場合についても加湿状態を計算し， $R H$ と $I_{\mathrm{w}}$ の分布を Fig. 10（a)，（b）に示した。
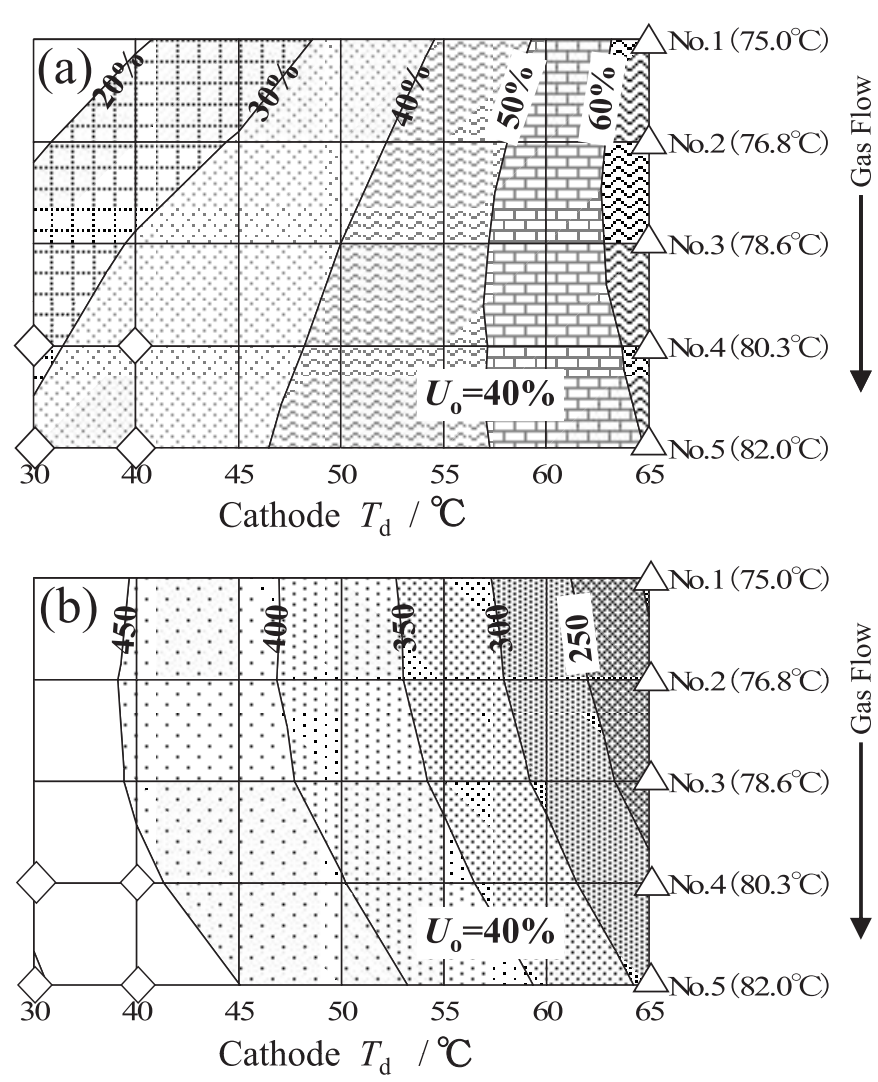

Water Flooding $(\bigcirc$ :strong, $\triangle$ :weak $), \quad$ Drying up $(\bowtie)$

Fig. 10 Distributions of (a) relative humidity, and (b) $\mathrm{H}_{2} \mathrm{O}$ vapor transportation index with thermal gradient along gas flow.

温度勾配をつけないFig. 7 (b)，Fig. 8（b）におけるフラ ッディング領域 $\left(45{ }^{\circ} \mathrm{C}<T_{\mathrm{d}}<60{ }^{\circ} \mathrm{C}\right.$ の下流セル) でFig. 10 (b) の $I_{\mathrm{w}}$ が大幅に大きくなるとともに, Fig. 10 (a) の $R H$ が低加湿側にシフトしており, セルの下流に向かって温度上 昇するように温度勾配をつけることにより，フラッディング が改善された実験結果と対応していることが分かる．注目す べきは $T_{\mathrm{d}}$ が低い場合に，Fig. 10（a）で示すRHの分布は下 流セルほど高加湿になっているが，Fig. 10（b）のI $I_{\mathrm{w}}$ の分布 図では，下流セルほど逆に低加湿になっていることを示して いる. 実際のセルではFig. 40白抜きマークで示すように下 流セルほどドライアップと見られる現象で性能が低下してお り， $I_{\mathrm{w}}$ の方が現実の MEAの加湿状態に対応した指標である と言える。これも $I_{\mathrm{w}}$ が温度に依存する飽和水蒸気圧を直接, 考慮しているからと考えられる.

また，着目するそれぞれの分割セルを低い空気利用率の $U_{0}=20 \%$ で単独作動させ，圧損による全圧減少がドライア ップ現象に及ぼす効果を検証した，Fig. 6の実験の場合の $R H$ と $I_{\mathrm{w}}$ の分布をそれぞれFig. 11 (a)，（b）に表した. 同じ 条件で全セル作動させた場合の Fig. 7 (a), Fig. 8（a）と比 較すると, 単独でセルを発電させた場合にはいずれの分布も 低加湿領域でドライアップが発生することを示しており, 実 験結果とよく対応している.

ドライアップとフラッディングに関する実験データの統一 的理解と MEA 内部の水輸送に関する現象把握のために, 本 

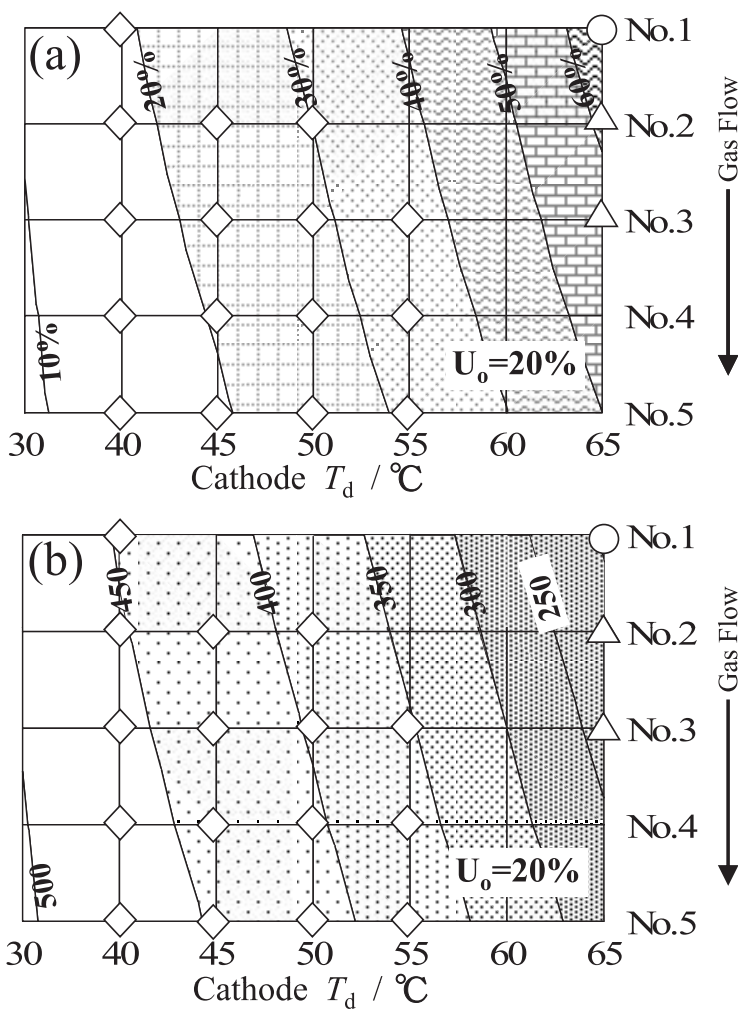

Water Flooding $(\bigcirc$ :strong, $\triangle$ :weak $)$, Drying up $(\diamond)$

Fig. 11 Distributions of (a) relative humidity, and (b) $\mathrm{H}_{2} \mathrm{O}$ vapor transportation index of segmented cell under each cell operations.

研究で導入した水蒸気輸送指標 $I_{\mathrm{w}}$ は, MEA 中に仮定した液 体水の蒸発面の深さに対応するものとして考えてきた。一方, 定義式（11）からは，発電によって生成する水蒸気を MEA 内部の濃度拡散でカソードオフガス中に排出するのに, 同じ 生成水蒸気量あたりどのくらいの水蒸気濃度差 (水蒸気圧差) が必要であるかの指標であるとも考えられる。したがって， 水蒸気の排出性の高い MEA では，一般にフラッディング限 界に対応する $I_{\mathrm{w}}$ は低くなるとともにドライアップ限界に対応 する $I_{\mathrm{w}}$ も低くなり, 逆に水蒸気の排出性の低いMEA では, いずれの限界に対応する $I_{\mathrm{w}}$ も高くなると考えられ，MEAに おける水分の排出性/保持性のパラメーターとして, MEA 設計上の有用性が高い.

\section{5 まとめ}

GDLの撥水性制御によって反応ガスの加湿状態に応じて ドライアップとフラッデングが再現性良く発現できるように したMEAを用いて, 電解質膜以外の構成部材を完全に分離 独立させた $5 つ の$ 分割セルからなり, 反応ガスが途中で逆流, 混合しないように構成した全体セルを試作し, カソードガス の作動条件がそれぞれの分割セルの特性と，全体特性に及ぼ す影響を解析した。

(1) アノードガスをフル加湿 $(R H=100 \%)$, セル温度を $75{ }^{\circ} \mathrm{C}$ に設定し, 各分割セルの特性をカソードガスのガス利
用率 $\left(U_{0}\right)$, ガス露点 $\left(T_{\mathrm{d}}\right)$, 電流密度 $(I)$ を変えて調べた 実験において,

・ガス利用率が高くなると，カソードガスの露点が高い高 加湿領域において，下流の分割セルほど性能が急激に低 下するフラッディング現象が見られた。

・それぞれの分割セルを定電圧で作動させた運転モードで は電流密度分布が得られ，高電流密度運転では下流の分 割セルでフラッディングによる性能低下が見られる一方 で，低電流密度運転では上流の分割セルにドライアップ によると目される性能低下が見られた。

・下流の分割セルで見られたフラッディングは, 下流の分 割セルほど温度を高くする温度分布をつけることによっ て，緩和，解消された。

・各分割セルの個別単独発電では, ガス圧損によって下流 セルでドライアップが発生した。

（2）MEA中に生成水の仮想的な蒸発面を想定した水輸送 の簡単なモデルを立てて，実際の特性デー夕を解析した。そ の結果，各分割セルに供給されるカソードガスの $\left(P \mathrm{~S}_{\mathrm{H}_{2} \mathrm{O}}\right.$ $\left.(T)-P_{\mathrm{H}_{2} \mathrm{O}}(\mathrm{n})\right) / I(\mathrm{n})$ を, 新たに水蒸気輸送指標 $I_{\mathrm{w}}$ として 整理することにより，作動条件ごとに異なっていた各分割セ ルのドライアップとフラッデイング現象をこれまでの相対湿 度による方法に比べて, より普遍的に実験結果と対応づけら れるようになった。

また,この「水蒸気輸送指標」によって, 材料, 構造によ って異なる, 様々な MEAの水分の排出性/保持性の評価に 利用できると考えられる。

\section{文 献}

1) N. Rajalakshmi, M. Raja, and K. S. Dhathathreyan, J. Power Sources, 112, 331 (2002).

2) M. Noponen, T. Hottinen, T. Mennola, M. Mikkola, and P. Lund, J. Applied Electrochem., 32, 1081 (2002).

3) T. A. Zawodzinski, C. Derouin, S. Radzinski, R. J. Sherman, Van T. Smith, T. E. Springer, and S. Gottesfeld, J. Electrochem. Soc., 140, 1041 (1993).

4) L. Kim, C. G. Chung, Y. W. Sung, and J. S. Chung, J. Power Sources, 183, 524 (2008).

5) P. J. Ferreira, G. J. laO', Y. Shao-Horn, D. Morgan, R. Makharia, S. Kocha, and H. A. Gasteiger, J. Electrochem. Soc., 152, 2256 (2005).

6) J. Inukai, K. Miyatake, K. Takada, M. Watanabe, T. Hyakutake, H. Nishide, Y. Nagumo, M. Watanabe, M. Aoki, and H. Takano, Angew. Chem. Int. Ed., 47, 2792 (2008).

7) L. Matamoros and D. Bruggemann, J. Power Sources, 161, 203 (2006).

8) M. Uchida, Y. Fukuoka, Y. Sugawara, N. Eda, and A. Ohta, J. Electrochem. Soc., 143, 2245 (1996).

9) M. Uchida, Y. Aoyama, N. Eda, and A. Ohta, J. Electrochem. Soc., 142, 463 (1995).

10) C. Y. Soong, W. M. Yan, C. Y. Tseng, H. C. Liu, F. Chen, and H. S. Chu, J. Power Sources, 143, 36 (2005).

11) H. C. Liu, W. M. Yan, C. Y. Soong, F. Chen, and H. S. Chu, J. Power Sources, 158, 78 (2006).

12) K. Teranishi, S. Tsushima, and S. Hirai, J. Electrochem. Soc., 153, 664 (2006). 